\title{
Characteristics of Open Access Journals in Six Subject Areas
}

\author{
William H. Walters and Anne C. Linvill
}

We examine the characteristics of 663 Open Access (OA) journals in biology, computer science, economics, history, medicine, and psychology, then compare the OA journals with impact factors to comparable subscription journals. There is great variation in the size of OA journals; the largest publishes more than 2,700 articles per year, but half publish 25 or fewer. While just 29 percent of OA journals charge publication fees, those journals represent 50 percent of the articles in our study. OA journals in the fields of biology and medicine are larger than the others, more likely to charge fees, and more likely to have a high citation impact. Overall, the OA journal landscape is greatly influenced by a few key publishers and journals.

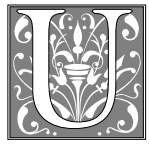

nlike subscription journals, Open Access (OA) journals are freely available online. Approximately 5 percent of academic and professional journals have adopted some type of OA publishing model, ${ }^{1}$ and the proportion is much higher in certain subject areas. For example, 27 percent of the 174 journals in the Web of Science general medicine and research medicine categories are Open Access, and another 14 percent are hybrid journals that provide free access after an embargo period or for certain types of articles. ${ }^{2}$

From September 2004 to August 2010, the number of titles listed in the Directory of Open Access Journals (DOAJ) rose from 1,250 to more than $5,200 .^{3}$ However, other evidence suggests that the number of new OA journals introduced each year has declined since its peak in 2001. ${ }^{4}$ In any case, OA journals appear to be growing in importance among college and university faculty. From 1997 to 2007, the proportion of scholars who reported knowing of one or more OA journals in their disciplines increased from 50 percent to more than 95 percent. By 2007, up to 40 percent of active scholars had published at least once in an OA journal. ${ }^{5}$ OA journals are also likely to benefit from a recent National Institutes of Health policy that mandates free online access to all NIH-funded research after an embargo period. ${ }^{6}$ Several European and international funding agencies have adopted similar requirements. ${ }^{7}$

Open Access journals have the potential to alter the system of scholarly communication and documentation in a number of ways. For example:

1. The absence of subscription charges may increase readership, especially among scholars in developing countries or at undergraduate colleges

William H. Walters is Dean of Library Services and Associate Professor of Social Sciences at Menlo College; e-mail: wwalters@menlo.edu. Anne C. Linvill is Access Services Librarian at Menlo College; e-mail: alinvill@menlo.edu. 
without comprehensive research libraries. ${ }^{8}$

2. The potentially lower costs of smallscale online publishing may allow the establishment of specialized journals that might not be economically viable under the conventional subscription model. In particular, OA publishing may increase the extent to which scholarly societies, academic departments, or other noncommercial publishers can disseminate scholarly work of local or regional interest. ${ }^{9}$

3. Greater accessibility, along with an increase in the number of specialized and regional journals, may encourage the publication of articles by authors outside the major North American and European research universities. However, this will be possible only if the publication fees charged by OA journals do not limit the participation of authors who do not have access to major research funding. ${ }^{10}$

While our study does not address these issues directly, it does investigate a set of related questions: How many OAjournals and articles are there? Who publishes them? Do noncommercial publishers have an especially significant role? Are publishers outside North America and Europe especially well represented? How common are publication fees, and what is the usual range of fees? Finally, do OA journal characteristics vary systematically by academic discipline or by publisher type?

This paper describes the characteristics of the journals listed in the Directory of Open Access Journals within six subject categories: biology, computer science, economics, history, medicine, and psychology. ${ }^{11}$ We present data on the size distribution of OA journals (articles per year) as well as information about publishers, dates of OA publication, countries and languages of publication, publication fees, and citation impact factors. The first part of the paper, "Characteristics of Open Access Journals," examines all 663 OA journals in the six subject areas. The second part, "Comparing OA and Subscription Journals," evaluates the differences between the 70 OA journals with impact factors and a set of 70 comparable subscription journals. This study updates previous research on OA journal characteristics, explores the differences between OA and subscription journals, and provides benchmark data that may be useful in future investigations.

Our analysis includes only active, refereed, English-language journals that provide free, immediate access to all journal content. While OA archives such as ArXiv and RePEc have gained prominence within certain subject areas, ${ }^{12}$ those archives are not peer-reviewed and are therefore not within the scope of our study.

\section{Previous Research}

Three previous studies have evaluated the general characteristics of OA journals. The most comprehensive investigation, by the Kaufman-Wills Group, presented 2005 data for several types of OA journals including a sample of 248 titles listed in DOAJ ${ }^{13}$ At the time of the Kaufman-Wills study:

1. The typical DOAJ journal published just 41 articles per year.

2. The fields of medicine, science, and technology accounted for 79 percent of all DOAJ journals.

3. Most DOAJ journals - 55 percentwere published by commercial (forprofit) publishers. No other type of publisher accounted for more than 15 percent of the total.

4. A small number of publishers-in particular, BioMed Central-published a relatively high proportion of all DOAJ journals.

5. Half the DOAJ journals had published their first online issue before 2000.

6. Forty-eight percent of DOAJ journals were published in North America 
and 41 percent in Europe. Just 11 percent were published elsewhere.

7. Forty-seven percent of DOAJ journals charged publication fees to authors or their institutions. Those fees accounted for 30 percent of the journals' revenue.

8. Relatively few DOAJ journals were widely cited. (Fewer than 8 percent provided citation data to the Kaufman-Wills Group, although some journals with citation data may have chosen not to respond.)

Because the journals in the KaufmanWills DOAJ sample are comparable to those we investigated, our presentation highlights the similarities and differences between our findings and theirs. We believe our results are more reliable, however, since our analysis is based on data for all 663 OA journals that met the criteria for inclusion in the study. The KaufmanWills data represent only 22 percent of the DOAJ journals - those whose editors or publishers responded to a survey. ${ }^{14}$ Although the Kaufman-Wills sample is adequate in size, it is not a random sample and does not fully represent the universe of OA publishers.

In 2006, Morris investigated the status and currency of the journals listed in DOAJ, reporting that 5 percent of the journals were inaccessible, partially inaccessible, or not true OA journals; that the median date of the first OA issue was 2000; and that the number of newly established OA journals rose consistently from 1990 to 2001 before declining slightly in each of the following three years. Morris also found substantial differences in size among the OA journals she investigated. ${ }^{15}$

More recently, Collins and Walters evaluated the characteristics of 166 DOAJ journals using much the same methods described here. ${ }^{16}$ Our analysis is significantly more thorough, however, and is based on the entire population of relevant DOAJ journals rather than a 25-percent sample. This study also presents a number of comparisons that could not have been undertaken with sample data.

\section{Methods}

\section{Scope of the Study}

Our analysis of OA journals includes only those that meet the following criteria:

1. are currently active;

2. are refereed (through conventional peer review or a similar process);

3. provide free, immediate access to the entire content of the journal; and

4. include some content in English (with or without content in other languages).

The first standard excludes nominally active journals that had not published any articles with a cover date of 2008 or 2009 as of April 2009. The second standard is intended to limit the analysis to scholarly publications. The third standard excludes journals that maintain barriers to access; after all, OA journals are not truly open if they rely on subscriptions (and subscriber-only access) to support their operations. The fourth standard was adopted mainly for pragmatic reasons, since we encountered substantial difficulty gathering detailed information for journals that were published solely in languages other than English.

We used the Directory of Open Access Journals to identify journals for the study, since nearly all the journals in DOAJ meet the second and third criteria listed above. ${ }^{17}$ We initially attempted to identify OA journals through other journal directories-EBSCONET, Open J-Gate, Open Science Directory, and Ulrichsweb-but found that none of them met our standards for scholarly OA content. All four include popular magazines as well as journals for which only some of the content is freely and immediately available. ${ }^{18}$ While the information in DOAJ is not completely reliable, ${ }^{19}$ no other source attempts to be comprehensive in its coverage of OA journals while excluding those that do not meet true OA standards. A small number of DOAJ journals are not peer-reviewed, ${ }^{20}$ but virtually all use some form of quality control.

Not all the DOAJ journals meet the first and fourth standards, so we browsed 
through recent issues to evaluate currency and language of publication. Although Morris reported in 2006 that a substantial number of DOAJ journals were no longer active, ${ }^{21}$ we found just a few titles that had not published any recent content. Englishlanguage journals were identified as those that had published any English-language material other than abstracts during the most recent 12 months.

Journal data were gathered in March, April, and May 2009 for each of the qualifying journals in six DOAJ subject areas: biology, computer science, economics, history, medicine (general), and psychology. We selected subject areas representing the life sciences, the physi$\mathrm{cal} /$ mathematical sciences, the social sciences, and the humanities, concentrating on disciplines with a substantial number of OA journals. Of the 868 DOAJ journals in the six subject areas, 663 met all four standards for inclusion in the study; 148 were excluded because they published no English-language content, and 57 were excluded for other reasons (not currently published, not refereed, or not truly OA).

\section{Characteristics of Open Access Journals}

For each of the 663 journals, we compiled a range of data:

1. articles per year;

2. publisher;

3. publisher type (commercial publisher, government, scholarly society, university, or other nonprofit publisher);

4. date of first OA issue (the cover date-not necessarily the online posting date);

5. country of publication;

6. language(s) of publication;

7. publication fee; and

8. subject category and 2007 impact factor, if the journal was included in Journal Citation Reports (JCR). ${ }^{22}$

All but the JCR data were found at the journals' or publishers' Web sites.

Articles per year (item 1 ) is the number of articles published over the most recent twelve months - for a quarterly, the most recent four issues; for a monthly, the most recent twelve issues. Special supplementary issues were also included. For journals published continuously rather than periodically, we counted the number of articles posted over the past 365 days. (Just a few journals had been published for less than a year. In those cases, we pro-rated the available data to arrive at an annual value.) The article counts include research articles, research notes, full-length review articles, case reports, editorials, and instructional essays. They do not include abstracts of conference papers, announcements, notices, book reviews, brief instructional essays ("Can you identify this lesion?"), errata, or letters to the editor.

The commercial publisher category (item 3) includes six companies for which publishing is a secondary activity. Likewise, the nonprofit publisher category includes 41 agencies that are engaged primarily in research, advocacy, or consulting rather than publishing. The university category includes university presses, academic departments, and other university-affiliated organizations. Sixteen publishers, representing 20 journals, could not be classified.

At 41 journals, the publication fee (item 7) is based on article length. At two journals, the fee is based on the number of authors. In calculating these charges, we assumed ten pages and two authors. Three journals charged submission fees, which we counted as if they were publication fees. Alternative methods of calculating page charges and submission fees produced no substantive changes in the results.

Significance tests were not conducted for the OA journals, since our data include the entire population of interest: the 663 DOAJ journals in six subject areas that met the four standards for inclusion in the study.

\section{Comparing $\mathrm{OA}$ and Subscription Journals}

Impact factors, representing the number of times a typical article is cited in the two 
years after its publication, are available through Journal Citation Reports for 70 of the 663 OA journals in our study. ${ }^{23}$ Only those journals that meet the JCR selection criteria-citedness, consistency of peer review, timeliness of publication, international diversity of editors and authors, and compliance with international editorial conventions-are assigned impact factors. ${ }^{24}$ A journal's business or access model has no bearing on the decision to include or exclude the journal, ${ }^{25}$ and the proportion of DOAJ journals with impact factors (11 percent) is comparable to the proportion of all academic journals with impact factors (10 to 12 percent). ${ }^{26} \mathrm{OA}$ and subscription journals with the same impact factor are therefore equal in citation impact-and, arguably, equal in quality.

We compared the 70 OA journals with impact factors to 70 comparable subscription journals. For each OA journal, we identified the English-language subscription journal in the same JCR subject category that had an impact factor closest to that of the OA journal. For instance, PLoS Biology (biochemistry and molecular biology, IF=13.501) was matched with Nature Chemical Biology (biochemistry and molecular biology, IF=13.683); Demographic Research (demography, IF $=0.835$ ) was matched with International Migration Review (demography, IF=0.852). If two or more journals had equally close impact factors, we chose the one with a fiveyear impact factor closest to that of the OA journal. If the OA journal appeared under multiple JCR subject categories, we checked each of them to identify the subscription journal with the closest impact factor. ${ }^{27}$

Our matching procedure appears to have been effective. The average difference in impact factors between the OA and subscription journals is less than 0.02 , and only 9 of the 70 matches resulted in discrepancies of 0.10 or more. For the OA journals, the average (median) impact factor is 2.30 (1.34); for the subscription journals, 2.28 (1.32).

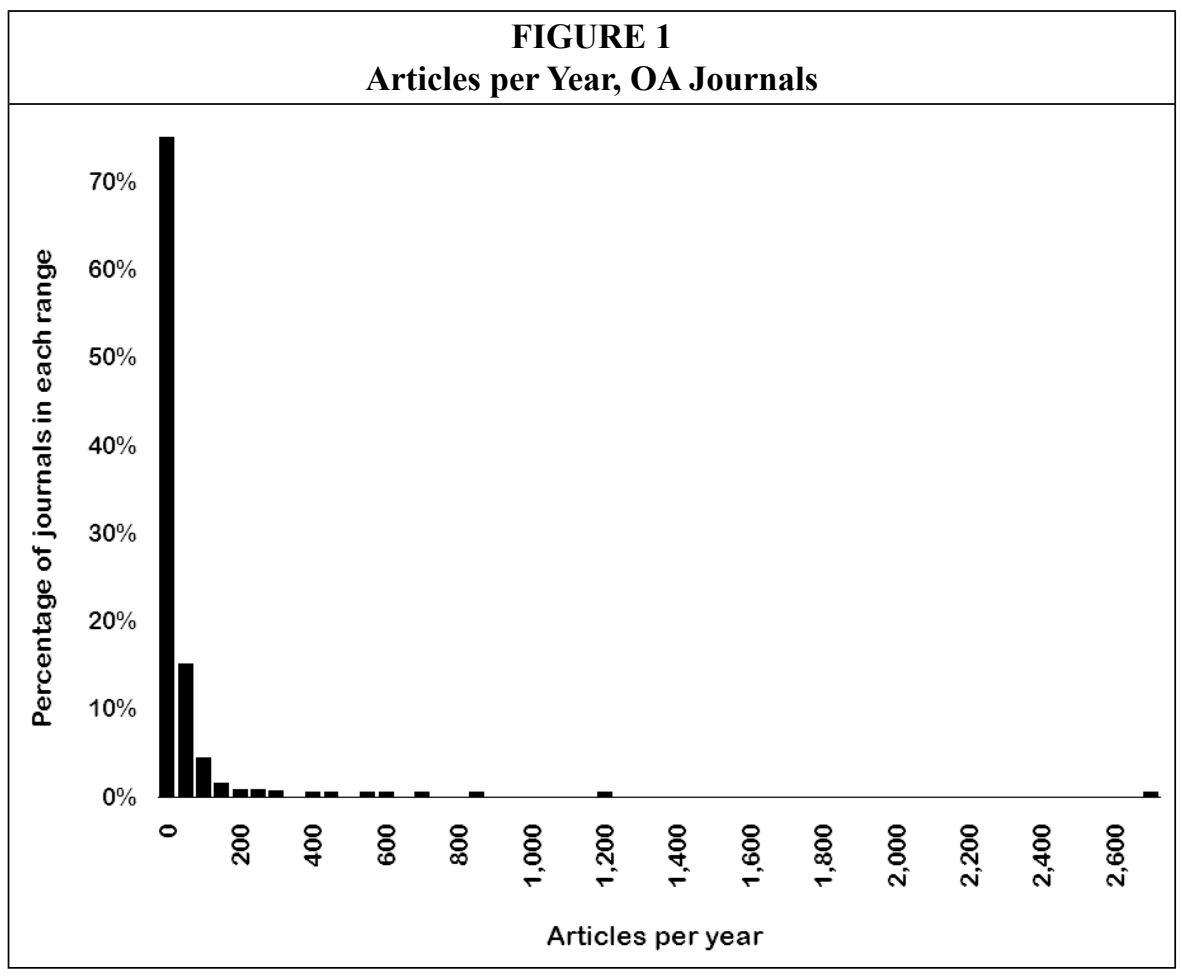


Information on the 70 subscription journals (such as articles per year and publisher) was compiled from the journals' and publishers' Web sites in October 2009.

Our data represent the entire population of relevant OA journals but just a subset (sample) of the corresponding subscription journals. We therefore conducted a significance test for each $\mathrm{OA} /$ subscription-journal comparison. In each instance, we tested whether the value for OA journals (or articles) with impact factors was significantly different from the value for subscription journals (or articles) with matching impact factors ( $p<0.10$, two-tailed). Each test was a one-sample $t$ test that compared the observed value for the sample of subscription journals with the expected value taken from the population of OA journals. $^{28}$

\section{Results}

\section{Characteristics of Open Access Journals}

Articles per year. The 663 OA journals vary dramatically in size (see figure 1 ). Fully 28 percent of them publish 13 or fewer articles per year. Half publish 25 or fewer articles per year, and 75 percent publish fewer than 50 . At the same time, the largest journal, PLOS ONE, publishes more than 2,700 articles per year. Together, the 20 largest OA journals account for more than a third of all the OA articles.

Within our study population, the average number of articles per year is $52-\mathrm{a}$ value somewhat higher than reported in previous research. ${ }^{29}$ The differences we found among subject areas (see table 1) are consistent with those described in earlier studies, however. OA journals in the life sciences typically publish more articles than those in computer science, economics, history, and psychology. On

\begin{tabular}{|c|c|c|c|c|c|}
\hline \multicolumn{6}{|c|}{$\begin{array}{c}\text { TABLE } 1 \\
\text { Number of OA Journals and Articles, by Subject and Publisher Type }\end{array}$} \\
\hline & $\begin{array}{l}\text { Number } \\
\text { of } \\
\text { Journals }\end{array}$ & $\begin{array}{l}\text { Total } \\
\text { Articles } \\
\text { per } \\
\text { Year }\end{array}$ & $\begin{array}{l}\text { Average } \\
\text { Articles } \\
\text { per } \\
\text { Year }\end{array}$ & $\begin{array}{l}\text { \% of } \\
\text { Journals } \\
\text { in Each } \\
\text { Category }\end{array}$ & $\begin{array}{l}\% \text { of } \\
\text { Articles } \\
\text { in Each } \\
\text { Category }\end{array}$ \\
\hline All Journals & 663 & 34,617 & 52 & 100 & 100 \\
\hline \multicolumn{6}{|l|}{ Subject } \\
\hline Biology & 135 & 10,653 & 79 & 20 & 31 \\
\hline Computer Science & 122 & 4,854 & 40 & 18 & 14 \\
\hline Economics & 64 & 2,637 & 41 & 10 & 8 \\
\hline History & 66 & 1,008 & 15 & 10 & 3 \\
\hline Medicine & 233 & 15,014 & 64 & 35 & 43 \\
\hline Psychology & 68 & 1,513 & 22 & 10 & 4 \\
\hline \multicolumn{6}{|l|}{ Publisher Type } \\
\hline Commercial & 188 & 8,243 & 44 & 28 & 24 \\
\hline Government & 13 & 474 & 36 & 2 & 1 \\
\hline Nonprofit & 92 & 7,751 & 84 & 14 & 22 \\
\hline Society & 139 & 7,173 & 52 & 21 & 21 \\
\hline University & 211 & 8,824 & 42 & 32 & 25 \\
\hline \multicolumn{6}{|c|}{$\begin{array}{l}\text { "Average Articles per Year" is the average number of articles per journal per year. } 25 \text { journals were } \\
\text { classified under more than one subject. } 16 \text { publishers (representing } 20 \text { journals) could not be classified } \\
\text { and are therefore omitted from the Publisher Type statistics. }\end{array}$} \\
\hline
\end{tabular}


average, OA journals in biology and medicine publish more than 60 articles per year, while those in history publish just 15 articles per year. Consequently, biology and medicine account for 55 percent of the journals but for 74 percent of the articles published in the six subject areas.

Subjects. As table 1 shows, more OA journals are published in biology and medicine than in computer science, economics, history, or psychology. Presumably, this reflects the greater number of scholars working in the life sciences, ${ }^{30}$ but it also corresponds to the practices of authors in each discipline. For instance, faculty in the biosciences publish almost exclusively in journals. As a group, they value rapid publication, strongly prefer online formats, and tend to be at least somewhat knowledgeable about Open Access. In contrast, authors in economics place less emphasis on rapid publication of articles, rely more heavily on working papers, and have mixed feelings about OA journals. In history, neither journal articles nor online access are central to the discipline, and historians are relatively slow to adopt innovations in scholarly communication. ${ }^{31}$

The representation of broad subject areas in our study is comparable to that reported by the Kaufman-Wills Group, who evaluated a sample of 248 DOAJ journals in all disciplines. They found that 45 percent of the DOAJ journals were in science and technology, 34 percent in medicine, 10 percent in the social sciences, and 7 percent in the arts and humanities. ${ }^{32}$ Our equivalent figures -38 percent, 35 percent, 20 percent, and 10 percent-suggest that our study population, while limited to six subject areas, is at least roughly representative of $\mathrm{OA}$ journals more generally.

Publishers. Our findings for publisher type differ substantially from those reported in previous research. The Kaufman-Wills Group reported that 55 percent of OA journals were commercially published, that 15 percent were published by universities, and that 16 percent were published by scholarly societies or other nonprofit agencies. ${ }^{33}$ Our results are markedly different: 28 percent commercial, 32 percent university, and 35 percent society/nonprofit (see table 1). Since our journals are comparable in subject to those evaluated by the KaufmanWills Group, the differences in publisher type may be attributed to changes in $\mathrm{OA}$ publishing that have occurred over the past five years. Nonprofits, and especially universities, may now play a greater role than they did in the past. Alternatively, the differences in publisher type may reflect a change in the editorial policies of DOAJ - an attempt to provide more comprehensive coverage of nonprofit and university-sponsored journals. Sampling bias may also have led the Kaufman-Wills Group to overestimate the proportion of DOAJ journals that were commercially published. $^{34}$

On average, the OA journals sponsored by nonprofit agencies publish more articles than the others. A similar disparity can be seen when we compare the commercially published journals (44 articles per year) with all the other types (53 articles per year). Table 2, which presents data on the most important OA journal publishers, suggests two reasons for the size disparity. First, the largest nonprofit publisher - the Public Library of Science (PLoS)-has four journals that together publish more than 3,500 articles per year. All four PLoS titles are among the largest OA journals in their subject areas, and the largest PLoS journal, PLOS ONE, accounts for 18 percent of all OA articles in the field of general medicine (see table $3)$. The second reason for the disparity in journal sizes can also be traced to a single publisher. BioMed Central, the largest commercial OA journal publisher, sponsors 49 specialty journals that together account for roughly the same number of articles as the four PLoS journals. Fifteen of the 49 BioMed Central journals publish fewer than 20 articles per year, and two publish fewer than 10 articles per year. As table 2 shows, the largest nonprofit 
OA publisher and the largest commercial OA publisher have adopted very different approaches, one focusing on a few large journals of broad scope (PLOS ONE, PLOS Biology, PLoS Medicine, and PLoS Computational Biology), the other publishing many smaller, specialized journals such as $B M C$ Bioinformatics and BMC Palliative Care.

Largest journals. Just as certain publishers shape the OA journal landscape, a few key journals are dominant within their subject areas. Along with PLOS ONE there is Nucleic Acids Research, which accounts for 12 percent of all the OA articles in the DOAJ biology category, and the International Journal of Computer Science and Network Security, which publishes 13 percent of all the OA journal articles in computer science (see table 3). The importance of the largest journals can be seen clearly in the field of economics, where the Annals of the University of Oradea and the Economics Bulletin together account for 44 percent of all the OA articles in the discipline. Especially large journals can also be found in psychology and history, where Forum: Qualitative Social Research and Nuevo Mundo-Mundos Nuevos publish 8 and 9 percent of all articles, respectively.

Issues available online. Twenty-two percent of the OA journals in our study provide online backfiles to 1999 or earlier. Five percent have pre-1990 backfiles. (One title, the Journal of the Medical Library Association, provides full text all the way back to the first issue of February 1898.) Forty percent of the OA journals provide coverage that begins between 2000 and 2004 (inclusive), while 38 percent provide coverage that begins in 2005 or later. These data are consistent with research which suggests that the annual number of newly established OA journals has been holding steady or declining slightly over time. ${ }^{35}$ There are no major variations by subject, except for the relatively high

\begin{tabular}{|c|c|c|}
\hline \multicolumn{3}{|c|}{$\begin{array}{c}\text { TABLE } 2 \\
\text { OA Publishers That Publish More Than } 6 \text { Journals or More Than } 400 \\
\text { Articles per Year }\end{array}$} \\
\hline Publisher and Publisher Type & $\begin{array}{c}\text { Number of } \\
\text { Journals }\end{array}$ & $\begin{array}{c}\text { Total Articles } \\
\text { per Year }\end{array}$ \\
\hline Public Library of Science (nonprofit) & 4 & 3,542 \\
\hline BioMed Central (commercial) & 49 & 3,388 \\
\hline Oxford University Press (university) & 2 & 1,270 \\
\hline University of Oradea (university) & 3 & 911 \\
\hline Academic Journals (type uncertain) & 1 & 858 \\
\hline Asian Network for Scientific Information (type uncertain) & 4 & 845 \\
\hline Intl. J. of Computer Sci. \& Network Security (nonprofit) & 1 & 628 \\
\hline Indian Academy of Sciences (society) & 2 & 582 \\
\hline Chinese Medical Association (society) & 1 & 561 \\
\hline World Acad. of Sci., Engineering \& Tech. (society) & 11 & 428 \\
\hline Hindawi Publishing Corporation (commercial) & 15 & 327 \\
\hline Medknow Publications (nonprofit) & 7 & 261 \\
\hline Bentham Open (commercial) & 25 & 240 \\
\hline Versita (commercial) & 7 & 235 \\
\hline Libertas Academica (commercial) & 9 & 183 \\
\hline Internet Scientific Publications (commercial) & 16 & 142 \\
\hline
\end{tabular}


TABLE 3

OA Journals That Publish More Than 200 Articles per Year, by Subject

\begin{tabular}{|c|c|c|}
\hline & $\begin{array}{c}\text { Total Articles } \\
\text { per Year }\end{array}$ & $\%$ Share \\
\hline \multicolumn{3}{|l|}{ Biology } \\
\hline Nucleic Acids Research & 1,234 & 12 \\
\hline African Journal of Biotechnology & 858 & 8 \\
\hline BMC Bioinformatics & 703 & 7 \\
\hline Current Science & 496 & 5 \\
\hline Pakistan Journal of Biological Sciences & 406 & 4 \\
\hline BMC Evolutionary Biology & 345 & 3 \\
\hline Research Journal of Biological Sciences & 311 & 3 \\
\hline PLoS Computational Biology & 306 & 3 \\
\hline Molecular Vision & 299 & 3 \\
\hline PLoS Biology & 293 & 3 \\
\hline \multicolumn{3}{|l|}{ Computer Science } \\
\hline Intl. J. of Computer Sci. \& Network Security & 628 & 13 \\
\hline Journal of Universal Computer Science & 212 & 4 \\
\hline \multicolumn{3}{|l|}{ Economics } \\
\hline Annals of the Univ. of Oradea: Econ. Sci. & 855 & 32 \\
\hline Economics Bulletin & 328 & 12 \\
\hline \multicolumn{3}{|l|}{ Medicine } \\
\hline PLoS ONE & 2,716 & 18 \\
\hline Chinese Medical Journal & 561 & 4 \\
\hline Singapore Medical Journal & 314 & 2 \\
\hline Journal of Korean Medical Science & 235 & 2 \\
\hline CMAJ: Canadian Medical Assn. Journal & 233 & 2 \\
\hline Swiss Medical Weekly & 233 & 2 \\
\hline Israel Journal of Medical Sciences & 231 & 2 \\
\hline PLoS Medicine & 227 & 2 \\
\hline
\end{tabular}

number of computer science journals (52 percent) for which no pre-2005 issues are available online.

Countries of publication. As might be expected, most OA journals that include English-language content are published in Europe or North America. At the same time, our findings confirm earlier reports that other regions of the world are especially well represented among $\mathrm{OA}$ publishers. ${ }^{36}$ After the United States and the United Kingdom, the top countries for OA journal publishing are not Germany or the Netherlands, but Brazil, Pakistan, India, Romania, Turkey, and Korea (see table 4). Our data also suggest that OA publishers outside Europe and North America have grown in importance over time. In 2005, just 10 percent of DOAJ journals were published outside Europe 


\begin{tabular}{|c|c|c|}
\hline \multicolumn{3}{|c|}{$\begin{array}{c}\text { TABLE } 4 \\
\text { Regions, Countries, and Languages of Publication }\end{array}$} \\
\hline & $\begin{array}{c}\% \text { of Journals in } \\
\text { Each Category }\end{array}$ & $\begin{array}{l}\% \text { of Articles in } \\
\text { Each Category }\end{array}$ \\
\hline \multicolumn{3}{|l|}{ Region } \\
\hline Europe & 43 & 39 \\
\hline North America & 25 & 26 \\
\hline Asia & 14 & 22 \\
\hline Central \& South America & 11 & 9 \\
\hline Oceania & 4 & 2 \\
\hline Africa & 2 & 1 \\
\hline \multicolumn{3}{|l|}{ Country (Top 10) } \\
\hline United States & 23 & 25 \\
\hline United Kingdom & 12 & 16 \\
\hline Brazil & 5 & 6 \\
\hline Pakistan & 2 & 5 \\
\hline India & 3 & 5 \\
\hline Romania & 2 & 4 \\
\hline Turkey & 4 & 4 \\
\hline Korea & 1 & 4 \\
\hline Japan & 3 & 3 \\
\hline Germany & 4 & 3 \\
\hline \multicolumn{3}{|l|}{ Language (Top 15) } \\
\hline English only & 73 & 80 \\
\hline English* & 100 & 100 \\
\hline Spanish* & 13 & 8 \\
\hline French* & 6 & 6 \\
\hline Portuguese* & 6 & 5 \\
\hline German* & 3 & 4 \\
\hline Romanian & 1 & 3 \\
\hline Japanese* & 2 & 1 \\
\hline Turkish & 1 & 1 \\
\hline Italian & 2 & 1 \\
\hline Croatian & 2 & 1 \\
\hline Russian* & 1 & 1 \\
\hline Serbian & 1 & 0 \\
\hline Lithuanian & 0 & 0 \\
\hline Catalan & 1 & 0 \\
\hline Chinese* & 0 & 0 \\
\hline
\end{tabular}




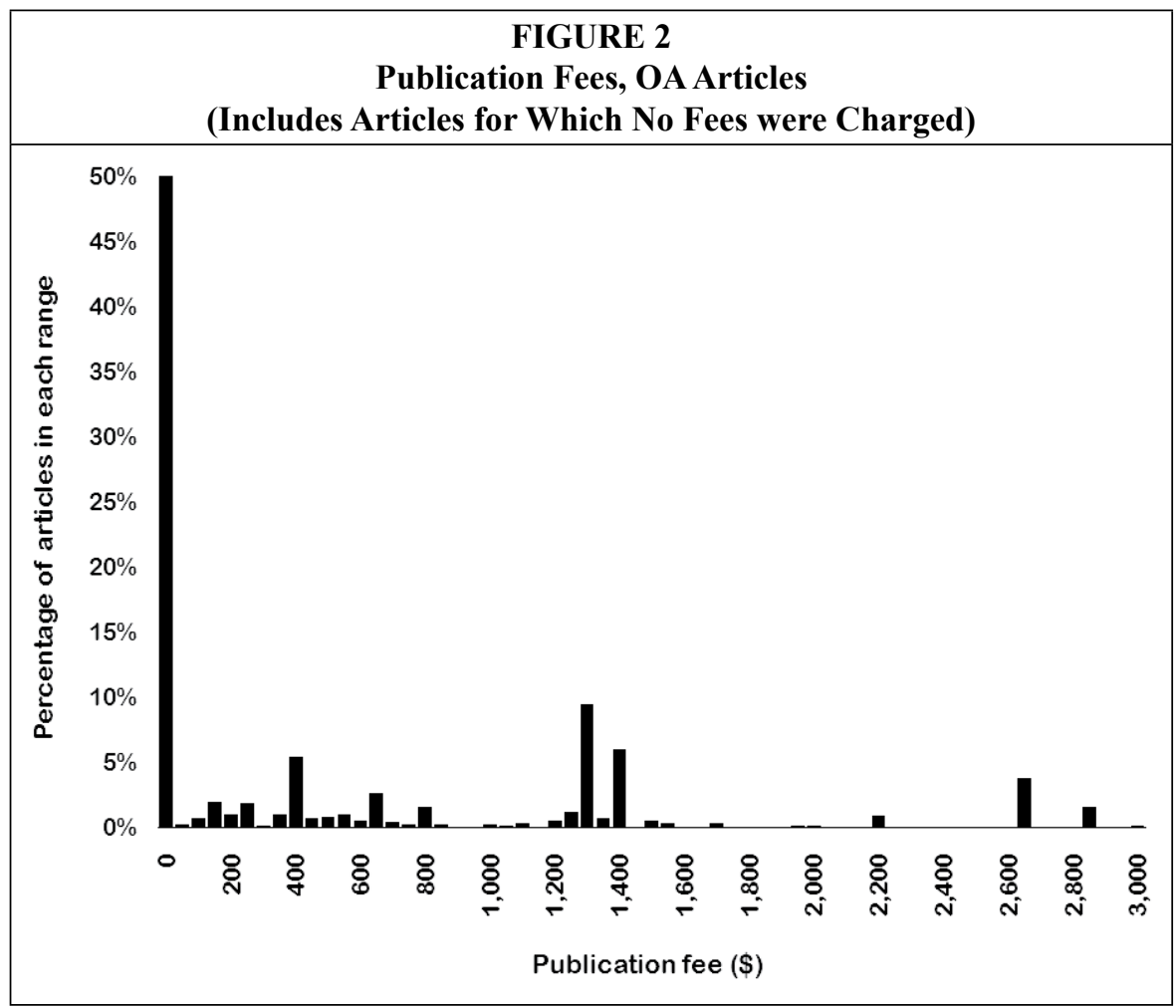

and North America; ${ }^{37}$ in 2009, 31 percent. (The change over time may actually be greater than these figures suggest, since the 2009 statistic includes only those journals that published at least some content in English.) As noted earlier, however, this apparent shift may be due at least partly to changes in the editorial policies of DOAJ.

Languages of publication. More than one quarter $(27 \%)$ of the journals in our study include articles in languages other than English. Eighteen percent publish in one other language, and 9 percent publish in at least two other languages. One journal, Diálogos: Revista Electrónica de Historia, includes articles in Catalan, English, French, Galician, Italian, Portuguese, and Spanish. The principal languages of the OA journals (see table 4) include eight of the ten most influential world languages - all but Hindi/Urdu and Arabic. ${ }^{38}$ However, several other languages are also prominent in the OA environment:
Romanian, Turkish, Italian, and Croatian, among others. Of the 177 journals that include content in languages other than English, a relatively high number (32 percent) are from Central or South America.

Publication fees. Many OA journals charge fees to authors or their institutions as a means of generating revenue. Because some OA journals publish far more articles than others (see figure 1), it is important to distinguish between journals and articles when drawing conclusions about OA publication fees. Just 29 percent of the journals in our study require the payment of fees, but those journals represent 50 percent of the articles. (The proportion of OA articles published by the fee-charging journals is substantially greater than the proportion of OA journals that charge fees, since the journals that charge fees tend to publish more articles per year.) This general finding is consistent with earlier research. ${ }^{39}$ At the same time, our figure for the proportion of journals that 
charge publication fees ( 29 percent) is significantly lower than that reported by the Kaufman-Wills Group (47 percent). ${ }^{40}$

Figure 2 illustrates the wide range of publication fees associated with the articles in our study. Further details can be seen in table 5, which shows marked differences across subject areas. Journals in the fields of biology and medicine are especially likely to charge publication fees. They also tend to charge the highest fees-up to $\$ 3,000$. In contrast, publication fees were levied for just over a third of the articles in computer science and economics, and none of the journals in those fields charged more than $\$ 800$. Likewise, OA journals in history and psychology seldom charge fees. No history journals require the payment of fees, and just 4 percent of the psychology journals do.

Table 5 also reveals substantial differences among the various types of publishers. Publication fees were assessed for 76 percent of the commercially published articles, but for just one third of the articles published by universities or scholarly societies. Perhaps surprisingly, nonprofit publishers (other than universities and societies) are most similar to commercial publishers in this regard; 58 percent of the OA articles published by nonprofit publishers require the payment of publication fees. Moreover, the median fees charged by commercial and nonprofit publishers are essentially the same: $\$ 1,295$ and $\$ 1,300$, respectively. The university-sponsored journals that charge publication fees require relatively high payments (median $=\$ 2,670$ ), while the society-sponsored journals tend to charge low fees (median= $\$ 400$ ).

Nine of the 16 largest OA publishers charge fees for virtually every article they publish (see table 6). Within that group, the highest fees are those of Ox-

\begin{tabular}{|c|c|c|c|c|c|c|}
\hline \multicolumn{7}{|c|}{$\begin{array}{c}\text { TABLE } 5 \\
\text { OA Publication Fees, by Subject and Publisher Type }\end{array}$} \\
\hline & $\begin{array}{l}\text { Journals } \\
\text { (\% with } \\
\text { Fees) }\end{array}$ & $\begin{array}{l}\text { Articles } \\
\text { (\% with } \\
\text { Fees) }\end{array}$ & $\begin{array}{l}\text { Median } \\
\text { Fee } \\
(\$)\end{array}$ & $\begin{array}{l}\text { Average } \\
\text { Fee } \\
(\$)\end{array}$ & $\begin{array}{l}\text { Minimum } \\
\text { Fee } \\
(\$)\end{array}$ & $\begin{array}{l}\text { Maximum } \\
\text { Fee } \\
(\$)\end{array}$ \\
\hline All Journals & 29 & 50 & 1,300 & 1,109 & 0 & 3,000 \\
\hline \multicolumn{7}{|l|}{ Subject } \\
\hline Biology & 56 & 69 & 1,395 & 1,319 & 75 & 3,000 \\
\hline Computer Science & 22 & 37 & 400 & 356 & 0 & 800 \\
\hline Economics & 6 & 34 & 150 & 307 & 80 & 800 \\
\hline History & 0 & 0 & - & - & - & - \\
\hline Medicine & 39 & 52 & 1,300 & 1,052 & 25 & 2,850 \\
\hline Psychology & 4 & 3 & 600 & 674 & 600 & 800 \\
\hline \multicolumn{7}{|l|}{ Publisher Type } \\
\hline Commercial & 69 & 76 & 1,295 & 1,036 & 70 & 2,000 \\
\hline Government & 0 & 0 & - & - & - & - \\
\hline Nonprofit & 13 & 58 & 1,300 & 1,367 & 100 & 2,850 \\
\hline Society & 18 & 33 & 400 & 422 & 25 & 3,000 \\
\hline University & 8 & 34 & 2,670 & 1,808 & 0 & 2,670 \\
\hline \multicolumn{7}{|c|}{$\begin{array}{l}\text { "Journals (\% with Fees)" is the percentage of journals that charge fees. "Articles (\% with Fees)" is the } \\
\text { percentage of articles for which fees were charged. The median, average, minimum, and maximum } \\
\text { fees refer to those articles for which fees were charged. }\end{array}$} \\
\hline
\end{tabular}




\begin{tabular}{|c|c|c|c|c|}
\hline \multicolumn{5}{|c|}{$\begin{array}{c}\text { TABLE } 6 \\
\text { Publication Fees Charged by OA Publishers That Publish More Than } 6 \\
\text { Journals or More Than } 400 \text { Articles per Year }\end{array}$} \\
\hline Publisher and Publisher Type & $\begin{array}{l}\text { Number } \\
\text { of } \\
\text { Journals }\end{array}$ & $\begin{array}{l}\text { Total } \\
\text { Articles } \\
\text { per } \\
\text { Year }\end{array}$ & $\begin{array}{l}\text { Articles } \\
\text { (\% with } \\
\text { Fees) }\end{array}$ & $\begin{array}{l}\text { Average } \\
\text { Fee } \\
(\$)\end{array}$ \\
\hline Oxford University Press (university) & 2 & 1,270 & 100 & 2,608 \\
\hline Public Library of Science (nonprofit) & 4 & 3,542 & 100 & 1,605 \\
\hline Libertas Academica (commercial) & 9 & 183 & 100 & 1,395 \\
\hline BioMed Central (commercial) & 49 & 3,388 & 96 & 1,382 \\
\hline Bentham Open (commercial) & 25 & 240 & 100 & 800 \\
\hline Hindawi Publishing Corporation (commercial) & 15 & 327 & 100 & 653 \\
\hline Academic Journals (type uncertain) & 1 & 858 & 100 & 650 \\
\hline Chinese Medical Association (society) & 1 & 561 & 100 & 400 \\
\hline $\begin{array}{l}\text { Intl. J. of Computer Sci. \& Network Security } \\
\text { (nonprofit) }\end{array}$ & 1 & 628 & 100 & 400 \\
\hline University of Oradea (university) & 3 & 911 & 33 & - \\
\hline $\begin{array}{l}\text { Asian Network for Scientific Information } \\
\text { (type uncertain) }\end{array}$ & 4 & 845 & 0 & 0 \\
\hline Indian Academy of Sciences (society) & 2 & 582 & 0 & 0 \\
\hline Internet Scientific Publications (commercial) & 16 & 142 & 0 & 0 \\
\hline Medknow Publications (nonprofit) & 7 & 261 & 0 & 0 \\
\hline Versita (commercial) & 7 & 235 & 0 & 0 \\
\hline $\begin{array}{l}\text { World Acad. of Sci., Engineering \& Tech. } \\
\text { (society) }\end{array}$ & 11 & 428 & 0 & 0 \\
\hline
\end{tabular}

ford University Press, BioMed Central (commercial), Libertas Academica (commercial), and Public Library of Science (nonprofit). The highest fees of all $(\$ 3,000)$ are associated with Molecular Systems Biol$o g y$, a journal of the European Molecular Biology Organization. Molecular Systems Biology has a very high citation impact but publishes just 54 articles per year.

Impact factors. As noted earlier, Journal Citation Reports provides impact factors for 70 of the 663 OA journals in our study. ${ }^{41}$ Table 7 reveals that the OA journals with impact factors are different from the other OA journals in several respects:
1. While the average OA journal publishes just 52 articles per year, those with impact factors are substantially larger: 148 articles per year. (Of the 22 OA journals that publish more than 200 articles per year, all but 8 have impact factors.)

2. More than 90 percent of the journals with impact factors can be found within the fields of biology or medicine.

3. A relatively high proportion of the journals with impact factors (33 percent) are published by scholarly societies, and a relatively low proportion (16 percent) are published by universities. 


\begin{tabular}{|c|c|c|c|c|}
\hline \multicolumn{5}{|c|}{$\begin{array}{c}\text { TABLE } 7 \\
\text { Characteristics of OA Journals and Articles With and Without Impact Factors }\end{array}$} \\
\hline & $\begin{array}{c}\text { All OA } \\
\text { Journals }\end{array}$ & $\begin{array}{l}\text { OA Journals } \\
\text { with IFs }\end{array}$ & $\begin{array}{l}\text { All OA } \\
\text { Articles }\end{array}$ & $\begin{array}{l}\text { OA Articles } \\
\text { with IFs }\end{array}$ \\
\hline Average Articles per Year & 52 & 148 & - & - \\
\hline \multicolumn{5}{|l|}{ Subject (\% in Each Category) } \\
\hline Biology & 20 & 51 & 31 & 62 \\
\hline Computer Science & 18 & 3 & 14 & 3 \\
\hline Economics & 10 & 4 & 8 & 1 \\
\hline History & 10 & 1 & 3 & 0 \\
\hline Medicine & 35 & 43 & 43 & 36 \\
\hline Psychology & 10 & 3 & 4 & 1 \\
\hline \multicolumn{5}{|c|}{ Publisher Type (\% in Each Category) } \\
\hline Commercial & 28 & 30 & 24 & 27 \\
\hline Government & 2 & 3 & 1 & 1 \\
\hline Nonprofit & 14 & 17 & 22 & 16 \\
\hline Society & 21 & 33 & 21 & 26 \\
\hline University & 32 & 16 & 25 & 22 \\
\hline \multicolumn{5}{|l|}{ Region (\% in Each Category) } \\
\hline Europe & 43 & 49 & 39 & 45 \\
\hline North America & 25 & 23 & 26 & 27 \\
\hline Asia & 14 & 20 & 22 & 22 \\
\hline Central \& South America & 11 & 9 & 9 & 5 \\
\hline Oceania & 4 & 0 & 2 & 0 \\
\hline Africa & 2 & 0 & 1 & 0 \\
\hline \multicolumn{5}{|c|}{ Language (\% in Each Category) } \\
\hline English only & 73 & 87 & 80 & 93 \\
\hline English & 100 & 100 & 100 & 100 \\
\hline Spanish & 13 & 7 & 8 & 2 \\
\hline French & 6 & 1 & 6 & 2 \\
\hline Portuguese & 6 & 4 & 5 & 3 \\
\hline German & 3 & 0 & 4 & 0 \\
\hline \multicolumn{5}{|l|}{ Publication Fee } \\
\hline$\%$ with Fees & 29 & 57 & 50 & 70 \\
\hline Average Fee (\$) & 923 & 1,171 & 1,109 & 1,409 \\
\hline
\end{tabular}


4. While just 29 percent of the OA journals in our study charge publication fees, the proportion is much higher among the OA journals with impact factors: 57 percent. The journals with impact factors also tend to charge somewhat higher fees.
As table 7 shows, most of these same relationships are apparent when articles, rather than journals, are considered.

The impact and importance of the very best OA journals is indisputable. Several of the journals listed in table 8 rank among the top ten journals (OA

\begin{tabular}{|c|c|c|c|}
\hline \multicolumn{4}{|c|}{$\begin{array}{c}\text { TABLE } 8 \\
\text { OA Journals with Impact Factors of } 2.0 \text { or Higher }\end{array}$} \\
\hline Journal and Country & $\begin{array}{l}\text { Impact } \\
\text { Factor }\end{array}$ & $\begin{array}{l}\text { Total Articles } \\
\text { per Year }\end{array}$ & $\begin{array}{l}\text { Average } \\
\text { Fee (\$) }\end{array}$ \\
\hline PLoS Biology (U.S.)* & 13.5 & 293 & 2,850 \\
\hline PLoS Medicine (U.S.)* & 12.6 & 227 & 2,850 \\
\hline Molecular Systems Biology (U.K.) & 10.0 & 54 & 3,000 \\
\hline CMAJ: Canadian Medical Assn. Journal (Canada) & 7.1 & 233 & 0 \\
\hline Nucleic Acids Research (U.K.)** & 7.0 & 1,234 & 2,670 \\
\hline PLoS Computational Biology (U.S.)* & 6.2 & 306 & 2,200 \\
\hline BMC Biology (U.K.) ${ }^{* * *}$ & 5.1 & 54 & 1,715 \\
\hline Molecular Pain (U.K.) ${ }^{* * *}$ & 4.1 & 67 & 1,295 \\
\hline BMC Evolutionary Biology (U.K.)*** & 4.1 & 345 & 1,435 \\
\hline Retrovirology (U.K.)*** & 4.0 & 119 & 1,225 \\
\hline DNA Research (U.K.)** & 3.5 & 36 & 500 \\
\hline BMC Bioinformatics (U.K.)*** & 3.5 & 703 & 1,435 \\
\hline BMC Molecular Biology (U.K.)*** & 3.4 & 111 & 1,435 \\
\hline BMC Developmental Biology (U.K.) ${ }^{* * *}$ & 3.3 & 120 & 1,435 \\
\hline Biology Direct (U.K.)*** & 3.3 & 54 & 1,295 \\
\hline BMC Cell Biology (U.K.)*** & 3.1 & 71 & 1,435 \\
\hline BMC Structural Biology (U.K.)*** & 3.1 & 55 & 1,435 \\
\hline Journal of Medical Internet Research (Canada) & 3.0 & 56 & 1,590 \\
\hline Intl. J. of Clinical and Health Psychology (Spain) & 2.9 & 59 & 0 \\
\hline Journal of Translational Medicine (U.K.)*** & 2.9 & 81 & 1,515 \\
\hline Biogeosciences (Germany) & 2.8 & 101 & 410 \\
\hline Journal of Machine Learning Research (U.S.) & 2.7 & 97 & 0 \\
\hline BMC Medical Genetics (U.K.)*** & 2.4 & 120 & 1,445 \\
\hline Molecular Vision (U.S.) & 2.3 & 299 & 0 \\
\hline Experimental and Molecular Medicine (Korea) & 2.3 & 71 & 780 \\
\hline Journal of Biomedical Science (U.K.)*** & 2.0 & 108 & 0 \\
\hline \multicolumn{4}{|c|}{$\begin{array}{l}\text { * Published by Public Library of Science (nonprofit). } \\
\text { ** Published by Oxford University Press. } \\
\text { *** Published by BioMed Central (commercial). } \\
\text { "Average Fee }(\$) \text { " refers to those journals for which fees were charged. }\end{array}$} \\
\hline
\end{tabular}


or otherwise) within their subject areas, and PLoS Biology and PLoS Medicine are both notable for having risen to top-five status just a few years after their first issues were published. ${ }^{42}$ These findings are consistent with those of McVeigh, who reported in 2004 that 14 OA journals ranked among the top 10 percent in their JCR subject categories. ${ }^{43}$ Of the 26 OA journals with impact factors of 2.0 or higher, all but two can be found in the DOAJ biology or medicine categories.

Although OA journals are published in a wide range of countries (see table 4 ), the 26 journals with impact factors of 2.0 or higher are nearly all published in North America or the United Kingdom (refer to table 8). The dominance of the British publishers is especially apparent. The United Kingdom accounts for just 12 percent of the journals and 16 percent of the articles in our study, but for 62 percent of the journals and 66 percent of the articles with impact factors of 2.0 or higher. In fact, just three publishers-BioMed Central (U.K.), Oxford University Press (U.K.), and the Public Library of Science (U.S.) - publish 18 of the 26 OA journals shown in table 8 .

\section{Comparing $\mathrm{OA}$ and Subscription Journals}

Table 9 presents comparative data for the 70 OA journals with impact factors and the 70 matching subscription journals. Although the two sets of journals are comparable in size (articles per year), they are significantly different with regard to publisher type, place of publication, language of publication, and publication fees. Specifically, the OA journals:

1. are far less likely to be commercially published, and more likely to appear in the nonprofit, society, and university categories;

2. are less likely to be published in Europe or North America, and more likely to be published in Asia;

3. are less likely to be published only in English; and

4. are far more likely to charge publication fees.
While 57 percent of the OA journals with impact factors charge publication fees, only 16 percent of the subscription journals do.

The primacy of English among the subscription journals is also noteworthy. Within our sample, both of the subscription journals with non-English titles (Zeitschrift fur Naturforschung C and Zentralblatt fur Neurochirurgie) are published exclusively in English, as are both of the journals sponsored by scholarly societies in Chinese-speaking countries (Chinese Science Bulletin and Journal of the Formosan Medical Association).

As table 9 shows, many of the differences between OA and subscription journals can also be seen at the article level. In particular, the difference in publication fees is even more dramatic when evaluated in terms of articles. Publication fees were levied for 70 percent of the articles in OA journals with impact factors but for just 15 percent of the articles in comparable subscription journals.

\section{Discussion}

As noted earlier, OA journals appear to hold special promise for both noncommercial publishers and publishers in developing countries. In comparison with subscription journals of equal citation impact, English-language OA journals are especially likely to be published by universities, scholarly societies, and other nonprofit agencies; by publishers outside Europe and North America; and in multiple languages. Moreover, the characteristics that make OA journals distinctive appear to be growing in importance over time. When considered in the context of earlier research, ${ }^{44}$ our analysis shows that universities, nonprofit/society publishers, and publishers outside Europe and North America each account for a higher proportion of OA journals in 2009 than they did in 2005.

However, these overall statistics understate the importance of several major British and American publishers. Just three publishers-PLoS, BioMed Central, 
TABLE 9

Comparison of OA and Subscription Journals and Articles (Those with Impact Factors)

\begin{tabular}{|l|c|c|c|c|}
\hline & $\begin{array}{c}\text { OA } \\
\text { Journals }\end{array}$ & $\begin{array}{c}\text { Subscription } \\
\text { Journals }\end{array}$ & $\begin{array}{c}\text { OA } \\
\text { Articles }\end{array}$ & $\begin{array}{c}\text { Subscription } \\
\text { Articles }\end{array}$ \\
\hline Average Articles per Year & 148 & 134 & - & - \\
\hline
\end{tabular}

Subject (\% in Each Category)

\begin{tabular}{|l|c|c|c|c|}
\hline Biology & 51 & - & 62 & - \\
\hline Computer Science & 3 & - & 3 & - \\
\hline Economics & 4 & - & 1 & - \\
\hline History & 1 & - & 0 & - \\
\hline Medicine & 43 & - & 36 & - \\
\hline Psychology & 3 & - & 1 & - \\
\hline
\end{tabular}

Publisher Type (\% in Each Category)

\begin{tabular}{|l|c|c|c|c|}
\hline Commercial & $30^{*}$ & 67 & $27^{*}$ & 66 \\
\hline Government & 3 & 1 & 1 & 3 \\
\hline Nonprofit & $17^{*}$ & 7 & $16^{*}$ & 7 \\
\hline Society & $33^{*}$ & 16 & 26 & 19 \\
\hline University & $16^{*}$ & 9 & $22^{*}$ & 4 \\
\hline
\end{tabular}

Region (\% in Each Category)

\begin{tabular}{|l|c|c|c|c|}
\hline Europe & $49^{*}$ & 61 & $45^{*}$ & 61 \\
\hline North America & $23^{*}$ & 36 & 27 & 36 \\
\hline Asia & $20^{*}$ & 3 & $22^{*}$ & 4 \\
\hline Central \& South America & 9 & 0 & 5 & 0 \\
\hline Oceania & 0 & 0 & 0 & 0 \\
\hline Africa & 0 & 0 & 0 & 0 \\
\hline
\end{tabular}

Language (\% in Each Category)

\begin{tabular}{|l|c|c|c|c|}
\hline English only & $87^{*}$ & 96 & 93 & 96 \\
\hline English & 100 & 100 & 100 & 100 \\
\hline Spanish & 7 & 0 & 2 & 0 \\
\hline French & 1 & 1 & 2 & 0 \\
\hline Portuguese & 4 & 0 & 3 & 0 \\
\hline German & 0 & 3 & 0 & 1 \\
\hline
\end{tabular}

Publication Fee

\begin{tabular}{|l|c|c|c|c|}
\hline \% with Fees & $57^{*}$ & 16 & $70 *$ & 15 \\
\hline Average Fee $(\$)$ & 1,171 & 1,100 & 1,409 & 1,032 \\
\hline
\end{tabular}

* The value for OA journals (articles) is significantly different from the value for subscription journals (articles) $(\mathrm{p}<0.10$, two-tailed).

"Average Articles per Year" is the average number of articles per journal per year. "Average Fee (\$)" refers to those journals and articles for which fees were charged. 
and Oxford University Press-account for 24 percent of the OA articles in our study and for 69 percent of the journals with impact factors of 2.0 or higher. The largest and most widely cited OAjournals are published by well-known nonprofit, commercial, and university presses in the United Kingdom and the United States. Nonetheless, it is noteworthy that two of the largest academic publishers, Elsevier and Wiley-Blackwell, are not among the top publishers of OA journals. (Springer has played a prominent role since their purchase of BioMed Central in 2008.)

Clearly, the Open Access landscape is not uniform or featureless. The journals published by PLoS and BioMed Central coexist with others sponsored by small scholarly societies or individual academic departments. Considerable variation can also be seen in the sizes of the various OA journals. While 14 of the journals in our study publish more than 300 articles per year, 129 publish 10 or fewer. Moreover, 81 journals publish no more than 7 articles per year-the same number published each day by PLOS ONE.

Because this study examined the characteristics of OA publishers rather than OA authors, we cannot say with confidence whether OA journals provide especially attractive publishing opportunities for authors at less research-intensive colleges and universities. However, our data suggest that publication fees are not a major barrier to authorship within the fields of computer science, economics, history, and psychology. Within those four disciplines, fewer than 25 percent of OA journals require the payment of fees. This is fortunate, since publication fees are a major factor in authors' decisions about where to submit their work. ${ }^{45}$

The situation is very different in biology and medicine, however, where fees are levied for more than 59 percent of all OA articles. In fact, the journals in the DOAJ biology and medicine (general) categories are different from the others in several respects. They publish more articles, they are more likely to be highly cited, and the fees they charge are roughly three times those of OA journals in the other four subject areas. All these findings are consistent with the recent emphasis on OA publishing in the life sciences. Because major biomedical funding agencies tend to support Open Access and may even require it, ${ }^{46}$ authors with grant funding sometimes have a special incentive to submit their work to OA journals. If that situation persists, submissions from grant-funded authors might eventually crowd out the papers submitted by other scholars.

This paper updates the work of the Kaufman-Wills Group ${ }^{47}$ and extends their analysis in certain respects. Nonetheless, there are a number of important questions that neither study has addressed. Some of these questions can be answered through the compilation and analysis of currently available evidence. For example:

1. What percentage of OA journals are no longer active? Does longevity vary with journal size or publisher type?

2. Does the relatively high number of university departments and scholarly societies among OA journal publishers coincide with a high degree of subject specialization, or with an emphasis on topics of regional or local interest?

3. Do OA journals increase the overall number of articles written by authors in developing countries, or do they simply publish articles that would otherwise have appeared in subscription journals?

4. How do OA journals set their publication fees? What factors have led to the wide variation in fees?

5. Do low labor costs in developing nations allow OA publishers to experiment with business models that would not be viable in higher-income countries? ${ }^{48}$ To what extent is OA publishing threatened by increasing labor costs in developing countries?

Other questions, are more likely to be answered only over time:

1. Will the PLoS strategy (a few large journals of broad scope) or the 
BioMed Central strategy (a greater number of small, specialized journals) prove more successful in the long run? Which strategy is more likely to be adopted by other OA publishers?

2. Will the foremost OA journals in the biomedical sciences serve as a model for others? Will OA journals in the other disciplines eventually publish more articles, charge higher fees, and achieve citation rates similar to those of the top subscription journals?

3. Is OA publishing compatible with the work of scholarly societies that rely on individual memberships (individual subscriptions) to subsidize their conferences, research grants, and other activities? ${ }^{49}$

4. Although print journals remain accessible if the publisher goes out of business, the same is not necessarily true of online journals. Can OA publishers guarantee permanent access to content even if their own business models prove unsustainable ${ }^{50}$ Can they allay scholars' more general concerns about the long-term preservation of digital resources? $?^{51}$
5. A recent survey of more than 35,000 faculty showed that the library's role in purchasing (leasing) information resources is now regarded as more important than its role as an information gateway, information archive, or center for teaching and research support..$^{52}$ Will the library be able to maintain a central role in the academic environment if scholarly papers are freely available online? Finally, this study confirms a methodological point that was introduced in an earlier paper. ${ }^{53}$ Because journals vary greatly in size, the characteristics of journal articles (OA or otherwise) can be substantially different from those of the journals in which they appear. For instance, 20 percent of the journals in our study, but more than 30 percent of the articles, can be found in the DOAJ biology category. Likewise, just 29 percent of the OA journals charge publication fees, but those journals represent 50 percent of the articles in our study. Investigations of scholarly publishing should perhaps focus on articles rather than journals, since it is articles-not journals - that authors write, students read, and scholars use in their work.

\section{Notes}

1. Stevan Harnad and others, "The Access/Impact Problem and the Green and Gold Roads to Open Access," Serials Review 30, no. 4 (Dec. 2004): 310-14.

2. Marie E. McVeigh and James K. Pringle, "Open Access to the Medical Literature: How Much Content Is Available in Published Journals?" Serials 18, no. 1 (Mar. 2005): 45-50.

3. Walt Crawford, "Is Free Too Expensive? Open Access and Libraries," in Charleston Conference Proceedings 2004, ed. Rosann Baziriian, Vicky H. Speck, and Beth R. Bernhardt (Westport, Conn.: Libraries Unlimited, 2006), 80-86; Lund University Libraries, Directory of Open Access Journals (2010), available online at www.doaj.org [Accessed 10 August 2010].

4. Sally Morris, "When Is a Journal Not a Journal? A Closer Look at the DOAJ," Learned Publishing 19, no. 1 (Jan. 2006): 73-76.

5. Jingfeng Xia, "A Longitudinal Study of Scholars' Attitudes and Behaviors Toward OpenAccess Journal Publishing," Journal of the American Society for Information Science and Technology 61, no. 3 (Mar. 2010): 615-24.

6. National Institutes of Health, "National Institutes of Health Public Access" (2010). Available online at http://publicaccess.nih.gov. [Accessed 10 August 2010].

7. Trinity College Dublin, "Funders' Requirements for Open Access" (5 Aug. 2009). Available online at www.tcd.ie/Library/riss/tara/funders-requirements.php. [Accessed 10 August 2010].

8. OA journals are accessed more often than comparable subscription journals, although there is no evidence of a short-term citation advantage. See Philip M. Davis and others, "Open Access Publishing, Article Downloads, and Citations: Randomised Controlled Trial," BMJ 337, no. 7665 (9 Aug. 2008): 343-45, available online at http://www.bmj.com/content/337/bmj.a568.full.pdf [Ac- 
cessed 10 August 2010].

9. David C. Prosser, "Between a Rock and a Hard Place: The Big Squeeze for Small Publishers," Learned Publishing 17, no. 1 (Jan. 2004): 17-22.

10. William H. Walters, "Institutional Journal Costs in an Open Access Environment," Journal of the American Society for Information Science and Technology 58, no. 1 (1 Jan. 2007): 108-20; William $\mathrm{H}$. Walters and Esther Isabelle Wilder, "The Cost Implications of Open-Access Publishing in the Life Sciences," BioScience 57, no. 7 (July/Aug. 2007): 619-25, available online at www.bioone.org/ doi/pdf/10.1641/B570709 [Accessed 10 August 2010].

11. Lund University Libraries, Directory of Open Access Journals.

12. Cornell University Library, $\operatorname{arXiv.org}(2010)$, available online at http://arxiv.org [Accessed 10 August 2010]; RePEc, RePEc: Research Papers in Economics (2010), available online at http://repec.org [Accessed 10 August 2010].

13. Kaufman-Wills Group, The Facts about Open Access (Worthing, West Sussex: Association of Learned and Professional Society Publishers, 24 Oct. 2005). Available online at www.alpsp.org/ ForceDownload.asp?id=70. [Accessed 10 August 2010].

14. Ibid.

15. Morris, "When Is a Journal Not a Journal?"

16. Cheryl S. Collins and William H. Walters, "Open Access Journals in College Library Collections," The Serials Librarian 59, no. 2 (2010): 194-214.

17. Lund University Libraries, Directory of Open Access Journals.

18. EBSCO Information Services, EBSCONET (2010); EBSCO Information Services, Open Science Directory (2010), available online at www.opensciencedirectory.net [Accessed 10 August 2010]; Informatics India, Open J-Gate (2010), available online at www.openj-gate.com/Search/ QuickSearch.aspx [Accessed 10 August 2010]; ProQuest, Ulrichsweb (2010).

19. Morris, "When Is a Journal Not a Journal?"; Hajar Sotudeh and Abbas Horri, “Tracking Open Access Journals Evolution: Some Considerations in Open Access Data Collection Validation," Journal of the American Society for Information Science and Technology 58, no. 11 (Sept. 2007): $1578-85$.

20. Robin Peek, "Counting OA Journals," Information Today 22, no. 11 (Dec. 2005): 17-18.

21. Morris, "When Is a Journal Not a Journal?"

22. Thomson Reuters, Journal Citation Reports, 2010.

23. Ibid.

24. James Testa, "The Thomson Reuters Journal Selection Process" (2010). Available online at http://thomsonreuters.com/products_services/science/free/essays/journal_selection_process. [Accessed 10 August 2010].

25. Marie E. McVeigh, “Open Access Journals in the ISI Citation Database: Analysis of Impact Factors and Citation Patterns" (Oct. 2004). Available online at http://science.thomsonreuters. $\mathrm{com} / \mathrm{m} / \mathrm{pdfs} /$ openaccesscitations2.pdf. [Accessed 10 August 2010].

26. Testa, "The Thomson Reuters Journal Selection Process."

27. We made just two exceptions for journals classified under multiple subject categories. For the Journal of the Medical Library Association, we used a matching journal in the medical informatics category rather than the information science and library science category, since the medical aspect of $J M L A$ is an important part of its subject profile. For Revista de Biologia Marina y Oceanografia, we used a matching journal in the marine and freshwater biology category rather than the oceanography category, since the matching oceanography journal focused on physical rather than biological oceanography.

28. When testing for differences between articles rather than journals, we set the number of cases equal to the true number of observations (the number of journals) rather than the number of articles represented by those journals. Specifically, each case (each journal) was weighted by the number of articles per year (for that particular journal) divided by the average number of articles per journal per year (for all the journals in the sample).

29. Kaufman-Wills Group, The Facts About Open Access; Morris, “When Is a Journal Not a Journal?"

30. National Center for Education Statistics, “Doctor's Degrees Conferred by Degree-Granting Institutions, by Field of Study: Selected Years, 1970-71 Through 2007-08," in Digest of Education Statistics 2009 (Washington, D.C.: U.S. Department of Education, Apr. 2010), 398. Available online at http://nces.ed.gov/pubs2010/2010013.pdf. [Accessed 10 August 2010].

31. Michael Dawson and Matthew Rascoff, Scholarly Communication in the Economics Discipline: A Report Commissioned by JSTOR (New York: Ithaka, 12 June 2006), available online at www.ithaka. org/publications/pdfs/JSTOR\%20Econ\%20Study\%20Report\%20Public\%20final1031.pdf [Accessed 10 August 2010]; Rebecca Griffiths, Michael Dawson, and Matthew Rascoff, Scholarly Communication in the History Discipline: A Report Commissioned by JSTOR (New York: Ithaka, 31 Aug. 2006), available online at www.ithaka.org/publications/pdfs/JSTOR\%20History\%20Study\%20Report $\% 20$ 
Public\%20final1031.pdf [Accessed 10 August 2010]; Meredith Quinn and Jennifer Kim, Scholarly Communication in the Biosciences Discipline: A Report Commissioned by JSTOR (New York: Ithaka, 26 Mar. 2007), available online at www.ithaka.org/publications/pdfs/JSTOR\%20BioSci\%20Study $\% 20$ Report\%20Public\%20final1031.pdf [Accessed 10 August 2010].

32. Kaufman-Wills Group, The Facts About Open Access.

33. Ibid.

34. Ibid, 6.

35. Kaufman-Wills Group, The Facts About Open Access; Morris, "When Is a Journal Not a Journal?"

36. Jutta Haider, “The Geographic Distribution of Open Access Journals" (poster presented at the Ninth World Congress on Health Information and Libraries, Salvador, Bahia, Brazil, 20-23 Sept. 2005), available online at www.soi.city.ac.uk/ ch696/icml9_poster_haider.pdf [Accessed 10 August 2010]; Mamiko Matsubayashi and others, "Status of Open Access in the Biomedical Field in 2005," Journal of the Medical Library Association 97, no. 1 (Jan. 2009): 4-11, available online at www.ncbi.nlm.nih.gov/pmc/articles/PMC2605039/pdf/mlab-97-01-4.pdf [Accessed 10 August 2010]; McVeigh, "Open Access Journals in the ISI Citation Database."

37. Kaufman-Wills Group, The Facts About Open Access.

38. George Weber, “The World's 10 Most Influential Languages" (Dec. 1997). Available online at www.andaman.org/BOOK/reprints/weber/rep-weber.htm. [Accessed 10 August 2010].

39. Collins and Walters, "Open Access Journals"; Walters and Wilder, "The Cost Implications of Open-Access Publishing."

40. Kaufman-Wills Group, The Facts About Open Access.

41. Thomson Reuters, Journal Citation Reports.

42. Ibid.

43. McVeigh, "Open Access Journals in the ISI Citation Database."

44. Kaufman-Wills Group, The Facts About Open Access.

45. Roger C. Schonfeld and Ross Housewright, Faculty Survey 2009: Key Strategic Insights for Libraries, Publishers, and Societies (New York: Ithaka, 7 Apr. 2010). Available online at www.ithaka. org/ithaka-s-r/research/faculty-surveys-2000-2009/Faculty\%20Study\%202009.pdf. [Accessed 10 August 2010].

46. National Institutes of Health, "National Institutes of Health Public Access"; Trinity College Dublin, "Funders' Requirements for Open Access."

47. Kaufman-Wills Group, The Facts About Open Access.

48. Hindawi Publishing Corporation, based in Cairo, has achieved financial success by relying on a local supply of well-educated, low-wage workers. See Nancy L. Maron, "Hindawi Publishing Corporation: The Open Access Contributor Pays Model," in Sustaining Digital Resources: An On-the-Ground View of Projects Today, eds. Nancy L. Maron, K. Kirby Smith, and Matthew Loy (New York: Ithaka, Nov. 2009), 73-80, available online at www.jisc.ac.uk/media/documents/ publications/general/2009/scaithakaprojectstoday.pdf [Accessed 10 August 2010].

49. This question may be of special concern within economics. See Dawson and Rascoff, Scholarly Communication in the Economics Discipline.

50. In their comprehensive review of revenue sources for online publishing, Guthrie and associates note that the "contributor pays" model adopted by many OA publishers has two potential weaknesses: (1) because revenue is generated only through initial publication, there is no revenue stream to support long-term access to content; (2) if a journal rises in stature, gains readers, and accepts a lower proportion of submissions, its use-related costs and submissionprocessing costs increase while its income remains the same. See Kevin Guthrie, Rebecca Griffiths, and Nancy L. Maron, Sustainability and Revenue Models for Online Academic Resources: An Ithaka Report (New York: Ithaka, May 2008), available online at www.ithaka.org/ithaka-s-r/strategy/ sca_ithaka_sustainability_report-final.pdf [Accessed 10 August 2010].

51 . While most faculty are comfortable with the loss of print journals at their own institutions, they also feel strongly that print copies should exist somewhere; see Schonfeld and Housewright, Faculty Survey 2009. For an overview of sustainable access, see William H. Walters, "Criteria for Replacing Print Journals with Online Journal Resources: The Importance of Sustainable Access," Library Resources and Technical Services 48, no. 4 (Oct. 2004): 300-04.

52. Schonfeld and Housewright, Faculty Survey 2009.

53. Collins and Walters, "Open Access Journals"; Walters and Wilder, "The Cost Implications of Open-Access Publishing." 